\title{
95 ROCZNICA POWSTANIA CZASOPISMA
}

W tym roku mija 95 lat od powstania „Ruchu Prawniczego, Ekonomicznego i Socjologicznego". Mijający okres skłania do refleksji i podsumowań nad rola, jaka spełniał „Ruch Prawniczy, Ekonomiczny i Socjologiczny” w polskim życiu naukowym. Sporządzenie swego rodzaju résumé naszej działalności redakcyjnej jest o tyle zasadne, że w swej długiej historii „Ruch” był czasopismem, które nie stroniło od podejmowania zagadnień szczególnie doniosłych i aktualnych dla Polski. Warto przy tym podkreślić, że historia „Ruchu” nieodłącznie wiąże się z historią Wydziału Prawa i Administracji Uniwersytetu im. Adama Mickiewicza w Poznaniu. Redaktorami naczelnymi „Ruchu” byli wybitni profesorowie: Antoni Peretiatkowicz, Alfred Ohanowicz, Zbigniew Radwański, Zygmunt Ziembiński i Maciej Zieliński, a obecnie funkcję tę pełni Teresa Rabska.

Jubileusz 95-lecia powstania naszego czasopisma zbiegł się z ukazaniem numeru 1/2016 „Ruchu”, w którym zamieszczono artykuły dotyczące współczesnych, goraceych dyskusji nad Trybunałem Konstytucyjnym i ochrona podstawowych zasad ustrojowych. Stanowi on znakomite świadectwo starań Redakcji o to, by „Ruch” był „czasopismem w ciagłym ruchu”, reagującym na istotne problemy pojawiające się we współczesnej Polsce. Postawy redaktorów naczelnych pozwoliły zachować niezależność czasopisma oraz jego silna pozycję wśród polskich czasopism naukowych. „Ruch” zawsze był pismem ogólnokrajowym, na łamach którego podejmowano problematykę doniosłą dla funkcjonowania państwa, jego gospodarki i społeczeństwa.

Podsumowaniem dotychczasowego dorobku i osiagnięć „Ruchu” były obchody Jubileuszu 85-lecia czasopisma, które odbyły się w 2006 r. Na spotkaniu tym Redaktor Naczelny „Ruchu” prof. Teresa Rabska we wnikliwy sposób przedstawiła działalność czasopisma, wskazując na jego unikatowy charakter. Jak mówiła: „fenomen "Ruchu“ przejawia się w zachowaniu ciągłości czasopisma i jego założeń wytyczonych u jego początków. Ciagłość tę rozpatrywać można w różnych aspektach: czasowym - »Ruch" jest jedynym czasopismem prawniczym o rodowodzie przedwojennym zachowujacym jednolity profil i odwołujacym się do swoich korzeni; merytorycznym - redaktorzy "Ruchu« zawsze dazżyli do utrzymania charakteru naukowego i zasięgu ogólnopaństwowego czasopisma, oraz do aktywnego zaangażowania w sprawy nauki i życia społecznego i gospodarczego Rzeczypospolitej. Ciagłość tę widać też $\mathrm{w}$ jego unikalnym interdyscyplinarnym charakterze, tj. łączeniu trzech dziedzin nauki: prawa, ekonomii i socjologii, czego szczególnym przykładem są zeszyty monotematyczne". 
Przez 95 lat „Ruch” stanowił platformę wymiany myśli przedstawicieli różnych dyscyplin naukowych. Na naszych łamach prezentowano poglądy formułowane z różnych perspektyw merytorycznych. Ale to co najbardziej charakterystyczne dla naszego czasopisma - to publikowanie badań dotyczących przemian gospodarki, przemian ustrojowych oraz transformacji polskiego społeczeństwa.

Ostatnie wydarzenia polityczne oraz spory wokół podstaw legitymizacyjnych działalności orzeczniczej Trybunału Konstytucyjnego każą nam przypuszczać, że również i w najbliższych latach na łamach „Ruchu” pojawiać się będą artykuły podejmujące najbardziej aktualne problemy z dziedziny prawa, ekonomii czy socjologii. Zapraszamy zatem do dalszej współpracy naukowców, tylko w ten sposób czasopismo nasze będzie miało szansę stać się „rzeczywistym ruchem” odpowiadajacym na aktualne zmiany pojawiające się w prawie, gospodarce i społeczeństwie.

Marek Smolak Sekretarz Redakcji 